\title{
Zapomniane podręczniki szkolne z serii „Zarysy Przyrody” (1865-1867) autorstwa Romana Pacewicza
}

W okresie międzypowstaniowym polityka oświatowa władz carskich skierowana była na umocnienie panowania domu Romanowych w Królestwie Polskim. Przejawiało się to w podporządkowaniu oświaty rosyjskim władzom administracyjnym i odsunięciu społeczeństwa polskiego od wpływu na nią. Zaprowadzono język rosyjski jako urzędowy (okres przejściowy 1832-1837)1 ${ }^{1}$, co znalazło odbicie w ustawie szkolnej z 1833 r. (wzorowanej na rosyjskiej ustawie z 1828 r.), z 1840 r. i z 1851 r. (reorganizacja gimnazjów filoloficznych zgodna z reformą szkół rosyjskich z 1849 r. $)^{2}$. Proces rusyfikacji szkolnictwa pogłębił się w latach 1838-1845, przejawiało się to poprzez utrwalanie w nim stanowości, zmniejszenie liczby szkół gimnazjalnych oraz uruchomienie szkół realnych. Centralnymi władzami oświatowymi w Królestwie Polskim były przejściowo od 1832 r. Komisja Rządowa Spraw Wewnętrznych, Duchownych i Oświecenia Publicznego, od 1833 r. Rada Wychowania Publicznego, a następnie od 1839 r. Warszawski Okręg Naukowy podległy bezpośrednio ministrowi oświaty w Petersburgu ${ }^{3}$.

* Dr, Państwowa Wyższa Szkoła Zawodowa im. prof. Stanisława Tarnowskiego w Tarnobrzegu.

1 J. Kucharzewski, Epoka paskiewiczowska. Losy oświaty, Warszawa-Kraków 1914, s. $151-152,181$.

2 Zbiór Przepisów Administracyjnych Królestwa Polskiego Wydział Oświecenia, 1868, t. 3, s. 529-531; J. Kucharzewski, Epoka..., s. 34-35, 115-123; J. Miąso, Szkolnictwo zawodowe w Królestwie Polskim w latach 1815-1915, Wrocław 1966, s. 86-89; H. Raczek, Gimnazjum lubelskie, [w:] Szkoła czterech wieków. Liceum ogólnokształcące im. Stanisława Staszica w Lublinie, red. R. Kucha, Lublin 1992, s. 104, 111.

${ }^{3}$ Mimo tych zmian nadal utrzymana była Rada Wychowania Publicznego do 1861 r., a następnie Tymczasowa Rada Wychowania (1861-1862) i Rada Wychowania (1863-1867). J. Kucharzewski, Epoka..., s. 217-226; T. Manteuffel, Centralne władze oświatowe na terenie b. Królestwa Kongresowego (1808-1915), Warszawa 1929, s. 28, 30-31, 58-68; R. Wroczyński, Dzieje oświaty polskiej 1795-1945, Warszawa 1996, s. 116-117. 
Po zamknięciu Uniwersytetu Warszawskiego młodzież mogła kształcić się tylko w Rzymsko-Katolickim Seminarium Głównym przemianowanym na Akademię Duchowną (1835-1867), Szkole Farmaceutycznej (1840-1857), Szkole Sztuk Pięknych (1844-1866), Instytucie Szlacheckim (1848), Szkole Weterynarii (1840-1858), Instytucie Gospodarki Wiejskiej i Leśnictwa w Marymoncie (1836-1862), Szkole Rabinów, 12 seminariach diecezjalnych i Instytucie Nauczycieli w Puławach oraz na kursach dodatkowych, które zostały zniesione w 1849 r. przy gimnazjach gubernialnych ${ }^{4}$.

Złagodzenie kursu rosyjskiej polityki względem Królestwa Polskiego nastąpiło po wojnie krymskiej, zapoczątkowała go reforma Aleksandra Wielopolskiego. W marcu 1861 r. zlikwidowano Warszawski Okręg Naukowy i reaktywowano Komisję Rządową Wyznań Religijnych i Oświecenia Publicznego. Ustawa z 20 maja 1862 r. przywracała szkolnictwu narodowy charakter, większą powszechność i dostępność do oświaty oraz dopuszczała do kierowania oświatą czynniki społeczne. Zaprowadziła: 5-letnie szkoły powiatowe i 7-letnie gimnazja filologiczne, między którymi istniała drożność. Ostatni, piąty rok nauki w szkołach powiatowych miał charakter specjalny i dawał wykształcenie: ogólne, pedagogiczne dla kandydatów na nauczycieli lub techniczne. Szkolnictwo żeńskie oddano w ręce prywatne, z wyjątkiem Instytutu Aleksandryjsko-Maryjskiego Wychowania Panien w Warszawie i Szkoły Wyższej Żeńskiej Rządowej w Warszawie. Obie te instytucje oświatowe były 6-klasowe. Instytut posiadał dodatkową klasę pedagogiczną w celu kształcenia guwernantek, a ukończenie Szkoły Żeńskiej dawało prawo wychowywania i nauczania domowego ${ }^{5}$.

W 1862 r. uruchomiono Szkołę Główną Warszawską, która posiadała 4 wydziały: matematyczno-fizyczny, prawa i administracji, filologiczno-historyczny oraz lekarski (powstał na bazie Akademii Medyko-Chirurgicznej utworzonej w 1858 r.). Szkoła Główna w 1869 r. została przekształcona w Cesarski Uniwersytet Warszawski (z rosyjskim językiem wykładowym od 1871 r.) $)^{6}$.

Wybuch i klęska powstania styczniowego oraz represje popowstaniowe stanęły na przeszkodzie rozwojowi szkolnictwa polskiego w Królestwie Polskim. Car zatwierdził w 1864 r. tzw. ustawy jugenheimskie likwidujące reformę szkolną A. Wielopolskiego i ujednolicające je ze szkolnictwem Cesarstwa ${ }^{7}$. Ustanowiono dyrekcje naukowe w każdej z 10 guberni, obsadzając stanowiska naczelników wyłącznie Rosjanami. W 1867 r. reaktywowany został Warszawski Okręg Naukowy, a na przełomie lat sześćdziesiątych i siedemdziesiątych XIX w. oświata w Królestwie Polskim uległa całkowitej rusyfikacji.

W takim okresie żył Roman Pacewicz, a opisane pokrótce wydarzenia miały bezpośredni wpływ na jego życie.

Urodził się jako drugie dziecko Kajetana Pacewicza i Pauliny z Łaźniewskich. Jego matka była córką Piotra Pawła Łaźniewskiego i Brygidy z Kamienieckich. Brygida Łaźniewska urodziła się ok. 1776 r. jako córka Kazimierza i Reginy mał-

4 W. Korotyński, Losy szkolnictwa w Królestwie Polskim, Warszawa 1906, s. 93; S. I. Możdżeń, Zarys historii wychowania (Cz. II - Wiek XIX-do 1918 roku), Kielce, 1993, s. 116-117.

5 K. Poznański, Reforma szkolna w Królestwie Polskim w 1862 r., Wrocław-Warszawa-Kraków 1968 , s. 250-252.

6 W. Korotyński, Losy..., s. 94-106.

7 K. Poznański, Reforma..., s. 283-285. 
żonków Kamienieckich. Jej rodzice byli kupcami mieszkającymi we wsi Bartodzieje koło Jedlińska. Zmarła 5 sierpnia 1831 r. i pochowana została w grobowcu na Cmentarzu Katedralnym w Sandomierzu ${ }^{8}$. Piotr Paweł Łaźniewski (w dokumentach występuje jako Paweł Łaźniewski) urodził się ok. 1765 r. jako syn Macieja i Katarzyny z Tymowskich małżonków Łaźniewskich zamieszkałych w województwie podlaskim. Jego ojciec był skarbnikiem bielskim. Piotr Paweł Łaźniewski był podsędkiem sądu policji prostej powiatu sandomierskiego. Zmarł 12 lutego $1837 \mathrm{r}$. i został pochowany razem z żoną na Cmentarzu Katedralnym w Sandomierzu9 ${ }^{9}$.

Paulina Łaźniewska urodziła się 6 lutego 1803 r. we wsi Wólka Modrzejowa ${ }^{10}$ w województwie sandomierskim (obecnie województwo mazowieckie, powiat lipski, gmina Rzeczniów) w parafii Grabowiec ${ }^{11}$. W wieku 26 lat w dniu 11 lutego 1830 r. poślubiła Kajetana Pacewicza. Był on adiunktem i dozorcą miast obwodu sandomierskiego w Sandomierzu i przed ślubem mieszkał przy ul. Panny Maryi nr 55. Urodził się ok. 1791 r. we wsi Bogucice w Galicji austriackiej, w cyrkule bocheńskim w parafii Mikluszowice (obecnie w województwie małopolskim, w powiecie bocheńskim w gminie Drwina). Rodzicami jego byli Franciszek i Franciszka z Jastrzębskich małżonkowie Pacewicz, za życia dziedzice wsi Bogucice ${ }^{12}$. Zapewne jego wiek (39 lat) oraz fakt, że był wdowcem ${ }^{13}$, skłoniły rodziców panny młodej do zawarcia w przeddzień ślubu (10 lutego 1830 r.) intercyzy z przyszłym mężem córki. Zgodnie z kontraktem przedślubnym rodzice Pauliny, jedynaczki, nie dali jej żadnego posagu, a jedynie zapewnili, że dzieci zrodzone z ich córki odziedziczą majątek ${ }^{14}$. Świadkami tego kontraktu byli Onufry Ambroziewicz - sekretarz Komisji Obwodu i Jan Englebert Gielg - kupiec sandomierski ${ }^{15}$.

Po ślubie udzielonym przez ks. Michała Tarapacińskiego ${ }^{16}$, proboszcza sandomierskiej katedry, w dniu 11 lutego 1830 r. nowożeńcy zamieszkali w kamienicy Łaźniewskich znajdującej się w rynku pod nr 16.

8 Archiwum Państwowe w Kielcach Oddział w Sandomierzu (dalej APS), Akta stanu cywilnego parafii katedralnej w Sandomierzu (dalej: USC katedra), R. 1831, sygn. 36, nr aktu zgonu 202, s. 117.

${ }_{9}^{9}$ APS, USC katedra, R. 1837, sygn. 42, nr aktu zgonu 40, s. 87.

10 APS, Akta Miasta Sandomierza (dalej: AMS), Księga meldunkowa ok. 1845 r., sygn. 170, s. 69-70.

11 APS, USC katedra, R. 1830, sygn. 35, nr aktu małżeństwa 4, s. 48.

12 Tamże.

13 Pierwsza żona Kajetana Pacewicza, Marianna była córką Andrzeja Iwanickiego i Joanny z Cygnerów, pochodzących z obwodu stopnickiego w województwie krakowskim. Zmarła 6 lipca $1828 \mathrm{r}$. w Sandomierzu, w wieku 38 lat. APS, USC katedra, R. 1828, sygn. 33, nr aktu zgonu 68, s. 75.

14 Łaźniewscy byli właścicielami posesji nr 16 przy Rynku w Sandomierzu. Z Taksy domów miasta Sandomierza Towarzystwa Ogniowego z 1818 r. posiadamy jej opis: „Possessya ta o iednem piętrze graniczy z prawey strony z domem JPni Sadowskiey, z lewey z domem Ziółkowskiego, składa się z następujących częśći, to jest $z$ Zabudowania mieszkalnego murowanego gątami Krytego o piętrze o wym. 42 × 20 x 12 łokci, oszacowanego na 2600 zł oraz Parkanu drewnianego z balów daszkiem Krytego o wym. $40 \times 0 \times 4$ łokcie, wartości 200 zł. Cyt. za J. Zub, Rynek sandomierski w początkach XIX wieku, „Zeszyty Sandomierskie” 2002, nr 16, s. 27. Kamienica ta do 1935 r. posiadała podcienia. Por. M. Buliński, Monografija miasta Sandomierza, Sandomierz 1879, s. 427.

${ }_{15}$ APS, Hipoteka nr 12, 10 lutego $1830 \mathrm{r}$.

${ }^{16}$ Ks. Michał Tarapaciński, kanonik honorowy kolegiaty (później katedry) sandomierskiej, podproboszczy katedry, zmarł w 1836 r., Archiwum Diecezjalne w Sandomierzu (dalej: ADS), Akta personalne ks. Tymowski ks. Tarapaciński; Consignatio Cleri saecularis ac regularis Dioecesis Sandomiriensis, Warszawa 1837, s. 114. 
Starsza siostra Romana Pacewicza urodziła się 18 stycznia 1831 r. Jak wynika $z$ aktu chrztu sporządzonego w 1832 r., prawie rok po jej narodzinach sakramentu chrztu udzielił ks. M. Tarapaciński podproboszcz katedry sandomierskiej. Ponadto zanotował, że „Dziecięciu temu na chrzcie prywatnym w domu z wody odbytym nadane zostały imiona Honorata Maryanna". Rodzicami chrzestnymi byli dziadek Paweł Łaźniewski i Maryanna Ciechomska, żona rejenta sandomierskiego ${ }^{17}$.

Podobnie wyglądała sytuacja z Romanem Pacewiczem, który urodził się 28 lutego 1834 r. o godzinie 10 przed południem. Akt chrztu sporządził ten sam ks. Tarapaciński w dniu 17 lutego 1835 r., czyli prawie rok po jego narodzinach. W akcie chrztu odnotowano, że został ochrzczony "na Chrzcie prywatnym w domu z wody odbytym”. Rodzicami chrzestnymi byli, podobnie jak w przypadku jego siostry Honoraty, dziadek Paweł Łaźniewski i Maryanna Ciechomska, żona rejenta sandomierskiego ${ }^{18}$.

Młodszy brat Romana Pacewicza urodził się 1 września 1835 r. o godzinie 10 wieczorem i po 11 godzinach zmarł w dniu 2 września. Na chrzcie świętym, udzielonym również z wody przez lekarza, nadano mu imię Idzi ${ }^{19}$.

Fakt dokonania chrztu z wody nowo narodzonych dzieci Pacewiczów sugeruje, że stan ich zdrowia nie rokował dobrze i zdecydowano się dokonać chrztu bez obecności kapłana.

Posiadamy stosunkowo skromne informacje o rodzinie Romana Pacewicza. Kajetan Pacewicz, jak odnotowano w „Kalendarzykach Politycznych” z lat 1834-1842, był adiunktem, dozorcą miast w obwodzie sandomierskim ${ }^{20}$. Zmarł 8 kwietnia 1842 r. w Sandomierzu i został pochowany na Cmentarzu Katedralnym. Jego śmierć zgłosili Paweł Merecki - prezydent miasta Sandomierza i Piotr Ulatowski - pocztmistrz z Sandomierza ${ }^{21}$. Dokładnego miejsca jego pochówku nie udało się ustalić. Paulina Pacewicz zmarła 20 listopada/2 grudnia 1881 r. ${ }^{22} \mathrm{Jej}$ śmierć osobiście zgłosili ks. Henryk Radomiński²3, wikary katedry i Józef SłomCzyński ${ }^{24}$, prezydent miasta Sandomierza.

Fakt odnotowania w księgach meldunkowych jako miejsca zamieszkania rodziny prezydenta miasta J. Słomczyńskiego i Pacewiczów tej samej kamienicy sugeruje, że jej część była wynajmowana przez właścicieli. Stanowiło to zapewne

\footnotetext{
17 APS, USC katedra, R. 1832, sygn. 37, nr aktu urodzenia 33, s. 11.

18 APS, USC katedra, R. 1835, sygn. 40, nr aktu urodzenia 10, s. 6.

19 Tamże, nr aktu urodzenia 61, s. 21; nr aktu zgonu 198, s. 100.

20 „Kalendarzyk Polityczny” 1834, s. 127; 1836, s. 162; 1837, s. 175; 1838, s. 203; 1839, s. 272;
} 1840, s. 274; 1841, s. 283; 1842, s. 272.

${ }^{21}$ APS, USC katedra, R. 1842, sygn. 47, nr aktu zgonu 46, s. 86.

22 APS, USC katedra, R. 1881, sygn. 86, nr aktu zgonu 206, s. 153.

${ }^{23}$ Ks. Henryk Radomiński (21.05.1857-16.10.1933), ojciec jego był naczelnikiem więzienia w Sandomierzu, ukończył seminarium duchowne w Sandomierzu i 23.05.1880 r. przyjął święcenia kapłańskie. Publikował w „Gazecie Radomskiej”, autor Katechizmu dla wiernych wyznania rzymsko-katolickiego ułożonego metodą poglądową. F.J. [F. Jop], Ś. P. Ks. Henryk Radomiński, „Kronika Diecezji Sandomierskiej" 1933, nr 11, s. 318-319.

24 Józef Słomczyński, sekretarz Magistratu Miasta Sandomierza od 1865 r., prezydent Sandomierza od 1874 r. (nie pełnił tej funkcji przynajmniej od 1884 r.). „Pamiatnaja Kniżka Radomskoj Gubierni" 1872 , s. $55 ; 1875$, s. 54; 1885 , s. 16. 
znaczący wpływ w dochodach Pacewiczów. Po wczesnej śmierci Romana Pacewicza, kamienicę odziedziczyła jego siostra Honorata ożeniona z Janem Wolskim.

Ze względu na późniejsze losy Romana Pacewicza warto wspomnieć, że $w$ odnotowanym akcie jego chrztu ${ }^{25}$ świadkiem był znajomy rodziny, sandomierski aptekarz, Antoni Haenne ${ }^{26}$. Roman Pacewicz pobierał nauki w Sandomierzu. Miało to miejsce ok. lat 1846-1850, o czym świadczy zachowana dedykacja na jego książce ${ }^{27}$. Po skończeniu czteroletniej szkoły powiatowej w Sandomierzu zapewne kontynuował naukę w gimnazjum w Radomiu przez okres przynajmniej trzech lat, tam uzyskał maturę. Jak wynika z ksiąg meldunkowych z lat czterdziestych i pięćdziesiątych XIX w., utrzymywał się pracując w aptece, ponieważ jego profesję określono jako „podaptekarz”28. Zapewne wykonywana praca skłoniła go do podjęcia studiów farmaceutycznych na wydziale lekarskim Szkoły Głównej Warszawskiej. W 1864 r., po pięciu latach nauki, otrzymał tam stopień prowizora farmacji2 ${ }^{2}$. Po uzyskaniu wyższego wykształcenia w latach 1864-1865 przyjął posadę nauczyciela przedmiotów fizyczno-matematycznych w Szkole Powiatowej Specjalnej we Włocławku ${ }^{30}$. Nie znamy przyczyn, dla których zrezygnował z tej pracy i powrócił do rodzinnego miasta. Brakuje konkretnych informacji dotyczących jego pobytu w Sandomierzu. Warto jednak odnotować fakt, że do Sandomierza przyjechał i tu się osiedlił Ignacy Karpiński, emerytowany profesor i rektor Szkoły Powiatowej, później Gimnazjum we Włocławku31. Zamieszkał w Sandomierzu,

${ }^{25}$ APS, USC katedra, R. 1835, sygn. 40, nr aktu urodzenia 10, s. 6.

${ }^{26}$ Antoni Haennel (ok. 1790-1861), urodził się w Opatowie, aptekarz, obywatel miasta Sandomierza, zmarł 3.05.1861 r., pochowany na Cmentarzu Katedralnym w Sandomierzu. P. Sławiński, Zabytki z Cmentarza Katedralnego, „Ucho Igielne” 1998, nr 16, s. 9.

${ }_{27}$ Tekst dedykacji na stronie przedtytułowej egzemplarza książki [R. Pacewicz], Zoologija treściwie zebrana dla użytku kształcącej się młodzieży płci obojej. I. z drzeworytami w tekście, (Zarysy przyrody / [Roman Pacewicz], cz. 1), Skład Główny w Księgarni J. Błaszkowskiego przy ul. Krakowskie Przedmieście Nr 395, (druk Aleksandra Ginsa), w $8^{\circ}$, Warszawa 1865, ss. 233, w zbiorach Biblioteki Wyższego Seminarium Duchownego w Sandomierzu, sygn. 45335: „Wielmożnemu Księdzu / Marcinowi Szubartowiczowi / koledze szkolnemu nayu- / przejmiej autor na pamiatkę / ofiarowuje / Roman Pacewicz / 1868". Jedynym księdzem w diecezji sandomierskiej w tym okresie o nazwisku Szubartowicz był Wawrzyniec, urodzony 25.07.1832 r. Mimo innego imienia na dedykacji z dużym prawdopodobieństwem można przyjąć, że była napisana właśnie dla niego. Pośrednio potwierdza to zachowany właśnie $w$ bibliotece sandomierskiego seminarium egzemplarz książki. Wawrzyniec Szubartowicz w Sandomierzu uczęszczał do szkoły powiatowej w latach 1846-1850, a następnie do seminarium duchownego. Święcenia kapłańskie przyjął w 1855 r., a od 1861 do swojej śmierci 22.11.1911 r. był proboszczem w parafii św. Pawła w Sandomierzu. ADS, Akta personalne ks. Wawrzyńca Szubartowicza 1855-1911.

28 APS, AMS, Księga meldunkowa z ok. 1845 r., sygn. 170, s. 69-70.

29 „Biblioteka Warszawska” 1864, t. 2, s. 461; Por. Spis wykładów w Szkole Głównej Warszawskiej w letnim półroczu roku naukowego 1863/4 się odbywających, Warszawa 1864, s. 41.

30 „Rocznik Urzędowy Królestwa Polskiego” 1864, s. 201; 1865, s. 305.

31 Ignacy Karpiński (1815 (1817?)-12.10.1895), nauczyciel w Szkole Obwodowej w Kaliszu (1838-1844), Gimnazjum w Piotrkowie (1844-1851), Szkole Powiatowej w Wieluniu (1851-1852), Gimnazjum w Radomiu (1852-1860), Gimnazjum w Płocku (1860-1862), Szkole Powiatowej/Gimnazjum we Włocławku (1862-1868). Autor: Nowe ogrodnictwo polskie, z nowymi poglądami na przemysł $i$ handel produktami naszych wyrobów i na inne ekonomiczne potrzeby dzisiejszej naszej społeczności, Warszawa 1877; Krótki rys ustroju dawnej Polski i poglądy na przyszłość, t. 1, Warszawa 1887, t. 2, Warszawa 1888. Szerzej: A. Massalski, Słownik biograficzny. Nauczyciele szkół średnich rządowych męskich w Królestwie Polskim 1833-1862, Warszawa 2007, s. 192-193. 
na przedmieściu Rybitwy, w dworku nazywanym Dworkiem Karpińskich, który kupił w 1866 r. Możemy tylko domniemywać, czy i jaki wpływ na decyzję Karpińskiego miała osoba Romana Pacewicza. Obaj zapewne znali się jeszcze z czasów, kiedy R. Pacewicz jako uczeń pobierał naukę w gimnazjum radomskim.

Roman Pacewicz zmarł 1 listopada 1868 r. w Sandomierzu o godz. 23.00, ukończywszy 34 lata. Jak odnotował w akcie zgonu ks. Jan Ziółkowski ${ }^{32}$, był byłym nauczycielem zamieszkałym w mieście Sandomierzu, gdzie się urodził ${ }^{33}$. Pochowany został w grobowcu dziadków ze strony matki. O tym, że pochodził z zamożniejszej sandomierskiej rodziny, świadczy fakt opisania przez ks. Melchiora Bulińskiego w monografii miasta nagrobka: „Pomnik czworokątny piramidalny Piotra Pawła Łaźniewskiego, podsędka sądu pokoju powiatu sandomierskiego, zmarłego w roku 1837, oraz Brygidy z Kamienieckich Łaźniewskiej, zmarłej w roku 1831. W tym grobie pochowany także Roman Pacewicz, profesor nauk przyrodzonych"34.

Zmiana polityki oświatowej w Królestwie Polskim spowodowała zapotrzebowanie na podręczniki do szkół średnich w języku polskim. W tym też trendzie należy rozpatrywać serię „Zarysy Przyrody”, której autorem był Roman Pacewicz. Ukazały się w niej cztery podręczniki. Pierwszy to Zoologija treściwie zebrana dla użytku kształcącej się młodzieży płci obojej35 i drugi Botanika treściwie zebrana dla użytku kształcącej się młodzieży płci obojejej, były wydane w Warszawie w 1865 r. nakładem Składu Głównego w Księgarni J. Błaszkowskiego ${ }^{37}$, a drukowane w Drukarni Aleksandra Ginsa ${ }^{38}$. Zaznaczyć jednak należy, że Botanika,

32 Jan Ziółkowski (5.06.1832-po 1878), urodzony w Ożarowie, stanu miejskiego, w Sandomierzu ukończył szkołę powiatową (1849) i seminarium duchowne (1850-1853), a w Warszawie Akademię Duchowną (1853-1857), wyświęcony na kapłana 29.06.1855 r. w Warszawie. W latach 1868-1869 był wikarym sandomierskiej katedry, następnie wyjechał za granicę w celach leczniczych. W 1878 r. przebywał w szpitalu św. Jana Bosko. ADS, Akta personalne ks. Jana Ziółkowskiego (1855-1878).

33 APS, USC katedra, R. 1868, sygn. 73, nr aktu zgonu 142, s. 147.

34 M. Buliński, Monografija..., s. 437.

35 [R. Pacewicz], Zoologija treściwie zebrana dla użytku kształcącej się młodzieży płci obojej. I. z drzeworytami w tekście, (Zarysy przyrody / [Roman Pacewicz], cz. 1), Skład Główny w Księgarni J. Błaszkowskiego przy ul. Krakowskie Przedmieście Nr 395, (druk Aleksandra Ginsa), w $8^{\circ}$, Warszawa 1865, ss. 233.

${ }^{36}$ [R. Pacewicz], Botanika treściwie zebrana dla użytku kształcącej się młodzieży płci obojej z wielu drzeworytami w tekście, (Zarysy przyrody / [Roman Pacewicz], cz. 2), Skład główny w Księgarni J. Błaszkowskiego przy ul. Krakowskie Przedmieście Nr 395, w 8 , Warszawa 1865, ss. 272.

37 Błaszkowski Józef (1811-29.10.1866) w 1845 r. przy ul. Krakowskie Przedmieście 411 w Warszawie założył księgarnię ze składem materiałów piśmiennych. W 1851 r. przeniósł się do lokalu po przeciwnej stronie ulicy pod nr 395 (później 24). W tym miejscu prowadził również wypożyczalnię książek i skład materiałów rysunkowych i malarskich. Od ok. 1852 r. prowadził działalność nakładową. Wydawał książki dla dzieci i młodzieży oraz podręczniki szkolne i pomoce do nauki języków obcych, które były wielokrotnie wznawiane. Po śmierci założyciela księgarnia była własnością J. Błaszkowskiej, a następnie T. Popławskiego (ok. 1889). Od 1898 r. skład główny nakładów firmy znajdował się w księgarni M. Arcta w Warszawie. Księgarnia funkcjonowała prawdopodobnie do 1905 r. J. Jachowski, Błaszkowski Józef, [w:] Słownik pracowników książki polskiej, red. I. Trejchel, Warszawa-Łódź 1972, s. 73.

38 Gins Aleksander Ryszard (ok. 1819-29.09.1908) w 1852 r. kupił Drukarnię Towarzystwa Misjonarzy Angielskich w Warszawie i prowadził ją przy ul. Elektoralnej 755 (1855), a później przy 
mimo że była drugą częścią serii „Zarysy Przyrody”, w całości ukazała się jako ostatnia pozycja. Natomiast Mineralogija treściwie zebrana dla użytku kształcącej się młodzieży płci obojga ${ }^{39}$, która ukazała się jako trzecia część serii, miała dwa wydania. Pierwsze wydanie miało miejsce w Warszawie w 1865 r. nakładem Składu Głównego w Księgarni Józefa Kaufmanna ${ }^{40}$. Drukowano je natomiast w Drukarni Jana Psurskiego. Wydanie drugie „poprawione i pomnożone" ukazało się dwa lata później w Warszawie w 1867 r. nakładem Składu Głównego w Księgarni J. Błaszkowskiego, a drukowane było w Drukarni Aleksandra Ginsa ${ }^{41}$. Mimo podjętych prób nie udało się dotrzeć do czwartej części serii. W związku z tym kłopot jest z podaniem pełnego ty-

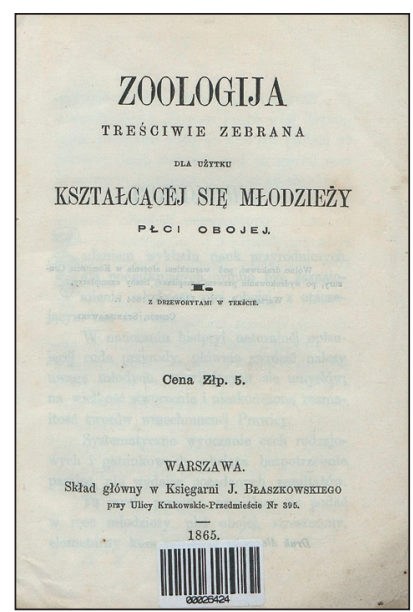
tułu tej publikacji. Reklama serii „Zarysy Przyrody” zamieszczona w Katechiźmie Chemii i Geognozyi rolniczej Profesora F. W. Johnstona podaje tytuł: „Kosmografija popularnie skreślona, z wielu drzeworytami w tekście - Warszawa 1865. Skład główny w księgarni J. Błaszkowskiego. Cena Złp. 3 gr. 10."42, Karol Estreicher odnotował tytuł: „Kosmografia, zarys świata słonecznego z wielu drzewor. w tekście przez R. P. w Włocławku. (Zarysy przyrody T. IV.). Warszawa, J. Błaszkowski, druk. Al. Ginsa, 1865, w 12ce, str. 93. 50 kop." ${ }^{\prime 3}$ Taki sam tytuł odnotował Feliks Kucharzewski ${ }^{44}$.

ul. Nowo-Zielnej 47. Drukarnia tłoczyła książki dla warszawskich firm nakładowych. Kolejnym właścicielem drukarni do 1909 r. był syn Henryk Adolf. J. Długosz, Gins Aleksander Ryszard, [w:] Słownik pracowników..., s. 262.

${ }^{39}$ [R. Pacewicz], Mineralogija treściwie zebrana dla użytku kształcącej się młodzieży płci obojga III., (Zarysy przyrody / [Roman Pacewicz], cz. 3), Skład główny w Księgarni Józefa Kaufmanna przy ul. Krakowskie Przedmieście Nr 442 (nowy 71) wprost odwachu, w 8', Warszawa 1865, ss. II, 105.

40 Józef Kaufmann na początku lutego 1860 r. otworzył w Warszawie przy ul. Krakowskie Przedmieście 442 (później 71) księgarnię i skład nut pod nazwą Józef Kaufmann i Sp. Początkowo prowadził ją wspólnie z Raimannem, a następnie z F. W. Hoesickiem (do 1862). Od 1867 r. prowadził wypożyczalnię nut. Nakładem Kaufamanna ukazywało się ok. 96 dzieł beletrystycznych, historycznych i popularnonaukowych w 103 tomach oraz czasopisma: „Bazar” - tygodnik dla kobiet (1865-1866), „Mucha” - tygodnik humorystyczny (1871 - sprzedany 1875), „Biblioteka Romansów i Powieści” - tygodnik (1872-1879) przekształcony w „Bibliotekę Romansów, Powieści, Podróży i Utworów Poetyckich” - tygodnik (1879 - sprzedany 1883), a także kalendarze: „Premiowy Kalendarz llustrowany” (1866-1874) i „Kalendarz Satyryczno-Humorystyczny” (1872-1873). M. Kocójowa, Kaufmann Józef, [w:] Stownik pracowników..., s. 402.

${ }^{41}$ R. Pacewicz, Mineralogija treściwie zebrana dla użytku kształcącej się młodzieży / skreślił Roman Pacewicz, wyd. 2 popr. i pomn., (Zarysy przyrody, cz. 3), Skład główny w Księgarni J. Błaszkowskiego, w $12^{\circ}$, Warszawa 1867.

42 F. W. Johnson, Katechizm Chemii i Geognozyi rolniczej Profesora F. W. Johnstona, przepolszczył Roman Pacewicz, Nauczyciel szkół. Dla użytku włościan i gospodarzy rolnych, w $8^{\circ}$, Warszawa 1865, s. 77.

${ }_{43}$ K. Estreicher, Bibliografia XIX stulecia, t. 3, Kraków 1962, s. 339.

44 Zob.: F. Kucharzewski, O astronomii w Polsce. Materiały do dziejów tej nauki w naszym kraju, Nakładem Biblioteki Kórnickiej, [Paryż] 1872, s. 224. 
Mówiąc o Romanie Pacewiczu jako o autorze podręczników, warto odnotować, że przetłumaczył na język polski wzmiankowany wcześniej Katechizm Chemii i Geognozyi rolniczej... James Finlay Weir Johnston ${ }^{45}$ w 1844 r. wydał książkę Catechism of Agricultural Chemistry. W Anglii doczekała się ona 33 wydań i została przetłumaczona na większość języków europejskich. Tłumaczenia na język polski podjął się Roman Pacewicz. Niestety, nie posiadamy żadnych informacji o jego znajomości języka angielskiego. Książka została dopuszczona do druku przez cenzurę 29.12.1864/10.01.1965 r. i ukazała się pod tytułem: Katechizm Chemii i Geognozyi rolniczej Profesora F. W. Johnstona, przepolszczył Roman Pacewicz, Nauczyciel szkót. Dla użytku włościan i gospodarzy rolnych ${ }^{46}$. Była wydana w październiku 1865 r. ${ }^{47}$ nakładem Składu Głównego w Księgarni Gebethnera i Wolffa ${ }^{48}$ przy ul. Krakowskie Przedmieście 415, a tłoczona w Drukarni Aleksandra Ginsa S-ka mniejsza. Jak podał R. Pacewicz w przedmowie tłumacza datowanej w Warszawie na 5 stycznia 1865 r.: „Rozpowszechnienie, a raczej zastosowanie jego [dzieła], znaczne dla rolnictwa rokuje korzyści, tem więcej, że będąc nadzwyczaj przystępnie i zrozumiale skreślone, może służyć jako przewodnik w gospodarstwie rolnem, dla umiejących czytać włościan. Dla gruntowniejszego jednak zrozumienia go pożądaną jest rzeczą, aby starszym uczniom w szkołach wiejskich, przez Nauczycieli

45 James Finlay Weir Johnston (13.09.1796, Paisley, Szkocja - 18.09.1855, Durham w północno-wschodniej Anglii), szkocki chemik rolny, kształcił się na Uniwersytecie w Glasgow, po ślubie w 1830 r. nabył majątek i poświęcił się studiom chemicznym, wykładowca Uniwersytetu w Durham, przebywał w Edynburgu. Napisał Catechism of Agricultural Chemistry (1844), w Anglii wydany 33 razy, przetłumaczony na większość języków europejskich oraz Chemistry of Common Life (1853/1855), strona internetowa: http://www.biographi.ca/009004-119.01-e.php?\&id_nbr=3990 [dostęp 03.10.2012].

46 F. W. Johnson, Katechizm Chemii i Geognozyi rolniczej Profesora F. W. Johnstona, przepolszczył Roman Pacewicz, Nauczyciel szkół. Dla użytku włościan i gospodarzy rolnych, w $8^{\circ}$, Warszawa 1865, ss. IV, 76.

47 W spisie nowości wydawniczych zamieszczono Katechizm... z informacją, że koszt jego nabycia wynosił 371/2 kopiejki. Kronika bibliograficzna, „Biblioteka Warszawska” 1865, t. 4, s. 625.

48 Firma Gustawa Gebethnera i Roberta Wolffa powstała w 1857 r. w Warszawie przy Krakowskim Przedmieściu 415. Działalność wydawniczą rozpoczęli w 1858 r. Gebethner i Wolff wydawali dzieła najwybitniejszych polskich pisarzy i poetów, literaturę dla dzieci i młodzieży, podręczniki szkolne, nuty oraz wydawnictwa periodyczne (m.in. „Tygodnik Ilustrowany”, „Kurier Warszawski”, „Kłosy”, „Tygodnik Powszechny”). Obok Składu Głównego w Warszawie firma posiadała filie w Krakowie, Poznaniu, Wilnie, Lublinie i Łodzi. Szerzej zob.: Z dziejów firmy Gebethner i Wolff. 1857-1937, oprac. J. Muszkowski, Warszawa 1938. 
było objaśnione; metoda katechizmowa o wiele naukę ułatwi" ${ }^{\prime 4}$. Wspomniana metoda katechizmowa polega na zadawaniu pytań i odpowiadaniu na nie. Jednocześnie $w$ tej publikacji zamieszczono liczne rysunki ilustrujące poruszane zagadnienia oraz mniejszą czcionką zaznaczono uwagi metodyczne ułatwiające demonstrację zjawisk. W tytule książki zaznaczono, że jest ona przeznaczona Dla użytku włościan i gospodarzy rolnych, jednak w tekście w uwagach metodycznych mamy odwołania na przemian do: nauczyciela, przewodnika, przewodniczącego, profesora czy objaśniającego.

Tłumacz w przedmowie zadeklarował, że jeśli wydane dzieło okazałoby się praktyczne, to zamie-

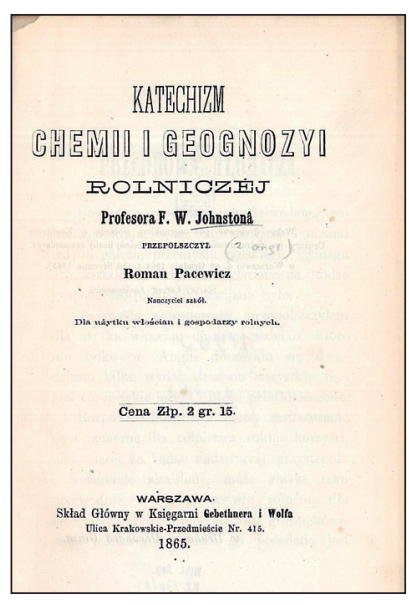
rza przetłumaczyć obszerniejszy kurs chemii i technologii rolniczej ${ }^{50}$. Niestety, nie udało się potwierdzić tego faktu.

Książki wydane w serii „Zarysy Przyrody”, z wyjątkiem drugiego wydania Mineralogii, nie są podpisane nazwiskiem i imieniem autora. Jedynie Przedmowy w poszczególnych częściach są sygnowane inicjałami Romana Pacewicza i tak: W Mineralogii w wydaniu pierwszym tylko literą „P.../Warszawa dnia 20 Lipca 1864 r.”; w Zoologii inicjałami „R. P./Włocławek 14 Października 1864 r.”; w Botanice inicjałami „R. P./Sandomierz d. 6 Sierpnia 1865 r.”

Interesujący jest również fakt reklamowania w Katechiźmie... wcześniejszych publikacji Romana Pacewicza, które ukazały się w serii wydawniczej „Zarysy Przyrody", jako tomów 1-4, a nie części. Przy reklamie książek podano również ceny, za jakie można było nabyć poszczególne egzemplarze. I tak Botanika... i Zoologia... były po 5 złp, Mineralogia... i Kosmografija... po 3 złp 10 gr., a Katechizm... po 2 złp $15 \mathrm{gr}$. Warto pamiętać, że w 1842 r. oficjalnie wprowadzono w Królestwie Polskim jako walutę ruble ${ }^{51}$. Podane ceny w złp były tej samej wartości podanej w rublach przez Karola Estreichera.

Ocena podręczników autorstwa Romana Pacewicza wydanych w serii „Zarysy Przyrody" ze względu na rozwój nauki dziś nastręcza wiele kłopotów. Warto odwołać się więc do recenzji z czasów współczesnych autorowi. Pierwszy artykuł krytycznie omawiający serię ukazał się na łamach „Gazety Warszawskiej” 19 września 1867 r.:

„Zarysy przyrody. P. Roman Pacewicz, którego Zoologia, Mineralogia i Kosmografia, w rysach wybitniejszych przedstawione, a przeznaczone głównie dla uczącej się młodzieży ukazały się w r. 1865, wydał obecnie dokończenie również w r. 1865 rozpoczętej Botaniki. Dziełko to, sposobem wykładu środkujące między pismami popularnemi a czysto szkolnemi, przystępne o ile w dzisiejszym stanie wysoko posuniętych nauk przyrodzonych traktowanie ich przystępnem być może,

49 R. Pacewicz, Przedmowa tłómacza, [w:] F. W. Johnson, Katechizm..., s. III-IV.

50 Tamże.

51 W 1841 r. miała miejsce reforma walutowa w Królestwie Polskim: 30 groszy polskich = 1 złoty polski $=15$ kopiejek; 100 kopiejek $=1$ rubel. 
zaleca się trafnym doborem szczegółów, jasnością i prostotą stylu. Wielka liczba drzeworytów, po większej części bardzo dobrze wykonanych, przychodząc w pomoc opisom, ułatwia objęcie rzeczy subtelniejszych, szczególniej fizyologii roślin, wcale starannie wypracowanej. Słabszą stronę dziełka stanowi chemia roślinna, wielce pobieżnie traktowana; rzecz to zresztą bodaj zupełnie niepodobna do spopularyzowania, a podawanie ostatecznych wywodów tej nauki na wiarę w «słowo honoru» piszącego, niekorzystnie mogłoby wpływać na kierunek umysłu młodzieży. Co do tego punktu czytelnik może znaleźć obfitsze szczegóły w innej pracy p. Pacewicza, Mineralogii, która obecnie wyszła w powtórnem wydaniu, znacznie pomnożonem i przerobionem według najnowszych pojęć nauki. Zarysy ogólne chemii są w tem wydaniu daleko obszerniej rozwinięte, a czerpane ztąd wiadomości mogą też służyć do lepszego zrozumienia tego przedmiotu w zastosowaniu do botaniki. Prace p. Pacewicza godne są zalecenia młodzieży i przewodnikom pierwszych jej kroków na pełnej manowców drodze nauk przyrodzonych. Szkoda tylko, że obok schludności druku, korrekta jest dosyć niedbała, tak, że myśl nawet niekiedy kaleczy. Np. w Botanice, str. 75, nitki zrobiono częścią słupka, kiedy istotnie są częściami pręcików, jak powiedziano na poprzedzającej karcie. Na str. 80 zawiązek owocowy po kilkakroć zowie się związkiem. W Mineralogii, str. 55, powiedziano, iż żelazo jest to «metal najużyteczniejszy, dla tego też (!) w przyrodzie bardzo rozpowszechnione». Podobne usterki w książce dla młodzieży przeznaczonej są skazą, której o ile można unikać potrzeba"52.

Druga recenzja, pióra Feliksa Kucharzewskiego, z 5 września 1871 r. omawia ogólnie materiały do dziejów astronomii i m.in. ocenia podręcznik Romana Pacewicza Kosmografia:

„Drugie zaś [dziełko astronomicznej treści - uwaga autora], stanowiące część IV Zarysów przyrody, dziełka poświęconego kształcącej się młodzieży, pod tytułem: Kosmografia, zarys świata słonecznego[ ${ }^{252}$ ], w r. 1865 w Warszawie wydane, jest pracą Romana Pacewicza, którą autor młodocianemu wiekowi i płci pięknej poświęcił; mieszcząc w sobie atoli wiele błędów, ciemnych określeń i śmiesznych często wniosków, z uważanych za zupełnie pewne domysłów wyprowadzonych, dziełko to raczej uczących się do kosmografii zniechęcić, niż pojęcie jej ułatwić i nią zająć może[253].

[252] W ósemce, stron 93, z 43 drzeworytami w texcie.

[253] Gruntowną recenzyą tej książki, najaką nawet nie zasługiwała, znaleźć można w Gazecie Polskiej z r. 1866, numerach 11 i $12^{\prime \prime 3}$.

\footnotetext{
52 Zarysy przyrody, „Gazeta Warszawska” 1867, nr 208, s. 2.

${ }^{53}$ F. Kucharzewski, O astronomii..., s. 224.
} 